\title{
Environmental influences on the relationship between juvenile and larval growth of Atlantic croaker Micropogonias undulatus
}

\author{
Steven P. Searcy ${ }^{1,2, *}$, David B. Eggleston ${ }^{2}$, Jonathan A. Hare ${ }^{3,4}$ \\ ${ }^{1}$ Department of Marine, Earth, and Atmospheric Sciences, North Carolina State University, Raleigh, \\ North Carolina 27695-8208, USA \\ ${ }^{2}$ School for Marine Science \& Technology, University of Massachusetts Dartmouth, 838 South Rodney French Boulevard, \\ New Bedford, Massachusetts 02744-1221, USA \\ ${ }^{3}$ NOAA, National Ocean Service, National Centers for Coastal Ocean Science, Center for Coastal Fisheries and Habitat \\ Research, 101 Pivers Island Road, Beaufort, North Carolina 28516-9722, USA \\ ${ }^{4}$ Present address: NOAA, National Marine Fisheries Service, Northeast Fisheries Science Center, Narragansett Laboratory, \\ 28 Tarzwell Drive, Narragansett, Rhode Island 02882-1199, USA
}

\begin{abstract}
For marine organisms with bipartite life cycles, there is growing recognition that juvenile traits may be dependent on previous larval history. The potential correlation between juvenile and larval stages is important to recognize, as growth rates in juvenile fish have been proposed to be an indicator of habitat quality. We investigated whether juvenile and larval growth are positively or negatively related using the estuarine-dependent fish Atlantic croaker Micropogonias undulatus as a model species. The relationship between juvenile and larval growth was examined using both a laboratory study, in which fish were held in individual containers with constant water temperature and salinity, and replicated field experiments, which spanned a range of environmental conditions. There was no relationship between juvenile and larval growth rates in the laboratory experiment. However, results from the field study suggest that a positive relationship between juvenile and larval growth was associated with high levels of freshwater runoff that displaced juvenile croaker from nursery areas to downstream habitats, in which they had reduced feeding success. Variability in the correlation between juvenile and larval growth for the 27 cohorts examined (fish hatched during the same 1 wk period) was independently explained by change in salinity (a proxy for freshwater runoff) and feeding ability (percentage of fish with empty stomachs). Future research should recognize the role that variable environments play in our ability to detect the relationship of life-history traits between ontogenetic stages.
\end{abstract}

KEY WORDS: Larval growth · Juvenile growth · Atlantic croaker · Freshwater runoff · Habitat quality

Resale or republication not permitted without written consent of the publisher

\section{INTRODUCTION}

In marine organisms with bipartite life cycles, there is growing recognition that larval and juvenile stages are not independent (Pechenik et al. 1998, Metcalfe \& Monaghan 2001, McCormick \& Hoey 2004). To date, most theoretical and empirical studies investigating processes that occur across life-history transitions in marine organisms have focused on how larval history influences age-, condition-, and length-at-metamor- phosis to the juvenile stage (e.g. McCormick 1994, Sponaugle \& Cowen 1994, Basch \& Pearse 1996). More recently, researchers have begun to investigate how larval traits influence juvenile survival (e.g. Searcy \& Sponaugle 2001, Bergenius et al. 2002) and juvenile growth rates (Searcy \& Sponaugle 2000, Phillips 2002, McCormick \& Hoey 2004).

With fishes, recognition of the potential dependence of juvenile growth on previous larval growth is critical, since juvenile growth rates have been proposed as a 
means to evaluate habitat quality (reviewed in Able 1999). The use of growth rates as an index of habitat quality is based on the widely held assumption that relatively high growth rates are a consequence of high-quality habitat (i.e. appropriate abiotic conditions, abundant food, and refuge from predators) (Sogard 1997). However, high juvenile growth rates could simply reflect larval characteristics. For example, previous studies of marine organisms have shown that small size at the larval-juvenile transition may be related to both slower (McCormick \& Molony 1992, Pechenik et al. 1998) and faster juvenile growth (Bertram et al. 1993). Similarly, relatively faster growing larvae may continue to grow rapidly as juveniles or have relatively slower juvenile growth (McCormick \& Hoey 2004). If growth rates result from the previous history of an individual, rather than specific characteristics of the current habitat type, then growth rates would be an inappropriate index of habitat quality.

Most studies investigating the relationship between larval and juvenile traits in marine organisms have been conducted in the laboratory (e.g. Bertram et al. 1993, Pechenik et al. 1996). More recently, studies of coral reef fishes have examined patterns of otolith growth to determine how larval and juvenile traits are related in the field (Searcy \& Sponaugle 2001, McCormick \& Hoey 2004). Otoliths (ear stones) of many fishes have daily rings, allowing estimates of age, hatch date, and age-specific growth history (e.g. Thorrold \& Hare 2002). We used the estuarine fish Atlantic croaker Micropogonias undulatus in both a controlled laboratory experiment and replicated field studies spanning a wide range of environmental conditions to test the null hypothesis that juvenile and larval growth are uncorrelated.

\section{MATERIALS AND METHODS}

Atlantic croaker Micropogonias undulatus is a commercially and recreationally important sciaenid fish that is a dominant component of the demersal nekton community along the Atlantic and Gulf coasts of the United States. Along the southeast US, Atlantic croaker spawn primarily over the continental shelf and have a protracted spawning season that extends from September through April (Hettler \& Chester 1990). Following pelagic larval development on the continental shelf, Atlantic croaker enter estuaries, and typically settle in low-salinity, upper-estuary channels, which they use as juvenile nursery areas (Ross 2003). The transition from larval to adult morphology is gradual (Able \& Fahay 1998); therefore, we designated lifehistory stage according to habitat type. The 'larval period' includes pelagic development occurring off- shore, the 'ingress period' includes movement from inlets to freshwater nurseries, and the 'juvenile period' occurs after settlement to nursery areas.

Otoliths. Caution is required when translating otolith growth rates into somatic growth rates, as otolith increment deposition is not always daily and periods of stress may decouple otolith and somatic growth (reviewed in Thorrold \& Hare 2002). Searcy (2005) validated daily otolith increment deposition for Atlantic croaker and found a positive relationship between otolith and somatic growth $(\mathrm{r}=0.41)$. Otolith growth was examined directly, to avoid errors in converting to estimates of somatic growth, as this approach provides a useful, albeit conservative, measure of fish growth (Chambers \& Miller 1995; $\mathrm{r}=0.41$, Searcy 2005).

To prepare otoliths for analysis, left sagittae were removed, mounted in epoxy, sectioned along the frontal plane, and polished to the core. All otoliths were examined using a transmitted light microscope at $400 \times$ magnification. Otolith images were captured with a frame grabber, on-screen magnification was doubled to $800 \times$, and increments were counted and distance between sequential increments was measured using Image-Pro Plus 4.5 image analysis software. Each otolith was analyzed a minimum of 2 times and if counts differed by $\leq 2$ increments, 1 reading was randomly chosen for analysis. If the increment counts differed by $\geq 3$ increments, the otolith was analyzed again. If the count from the third independent reading differed by $\leq 2$ increments from one of the former readings, 1 reading was randomly chosen for analysis, and if the count still differed by $\geq 3$ increments, the otolith was discarded from further analysis. The 'acceptable' ageing error was $6.7 \%$ for $30 \mathrm{~d}$ old fish (2 of 30 increments) and decreased correspondingly for older fish. In total, $3 \%$ of otoliths (3 of 100) from the laboratory study and $7.8 \%$ of otoliths (198 of 2550) from the field study were discarded.

Laboratory experiment. The laboratory experiment examined whether variability in growth of juvenile Atlantic croaker could be explained by larval traits, including (1) size at estuarine ingress, (2) age at estuarine ingress, and (3) larval otolith growth. The goal of the laboratory experiment was not to mimic patterns of growth found in the field, but to determine if, in the absence of environmental variability, juvenile growth was correlated with previous larval growth.

Collection method: Atlantic croaker $(\mathrm{n}=100)$ were collected during estuarine ingress at a mid-estuary station in North Carolina's Newport River estuary during night-time flood-tide on November 23, 2003, with a passively fished $0.5 \mathrm{~m}^{2}$ plankton net with $1 \mathrm{~mm}$ mesh (Fig. 1). Length and age measurements of croaker sampled at the mid-estuary station provide a reason- 


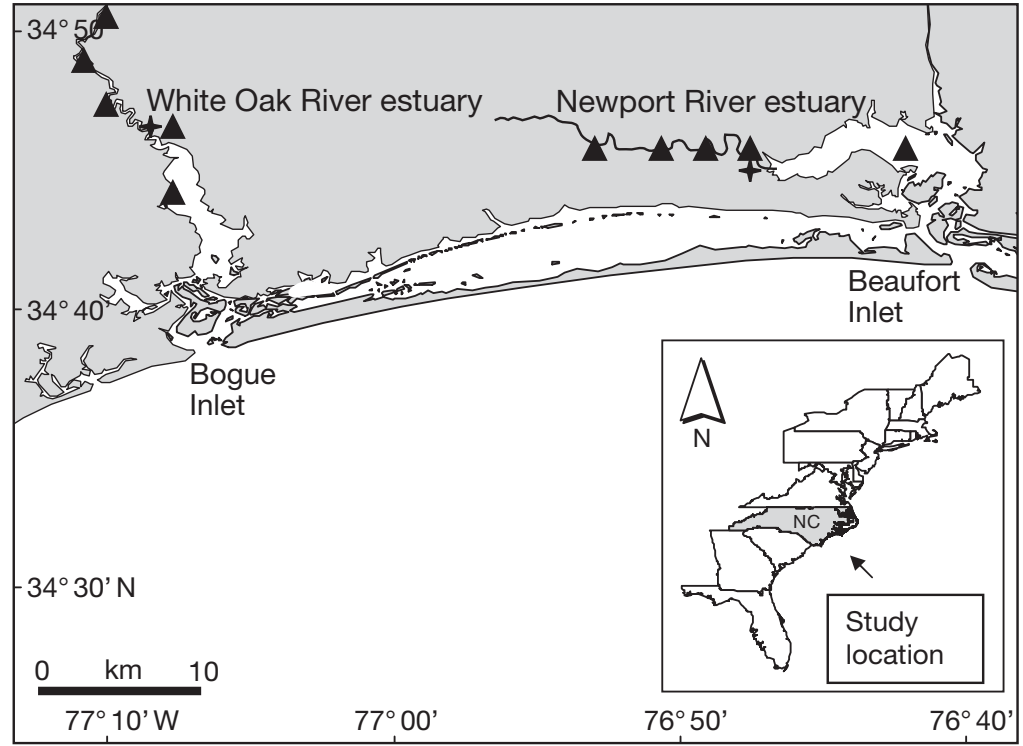

Fig. 1. White Oak River and Newport River estuaries, North Carolina, USA. Location of upper-estuary beam-trawl $(\mathbf{\Delta})$ and deployment site of YSI-6600 multiparameter dataloggers ( + ). Inset shows location of study area in relation to US East Coast

able approximation of length- and age-at-estuarineingress, as movement from inlet to nursery areas in the study region has been estimated to be a 1 to $3 \mathrm{~d}$ process (Searcy 2005). To help differentiate the larval and juvenile periods for subsequent analyses, the otoliths of each fish were marked by placing all fish in a $20 \mathrm{l}$ aquarium containing $18 \mathrm{ppt}$ estuarine water from the collection site, combined with a $100 \mathrm{mg} \mathrm{l}^{-1}$ solution of alizarin complexone (Ahrenholz et al. 1995) for $24 \mathrm{~h}$ immediately after capture. Otolith increments prior to the alizarin mark were assumed to represent 'larval' growth that occurred in the marine environment and otolith increments after the alizarin mark were considered 'juvenile.'

Following removal from the alizarin stain solution, each fish was placed in an individual 0.951 container ( $n=100)$, held in a controlled temperature water bath at $15^{\circ} \mathrm{C}$, and exposed to ambient photoperiod. Over the next $2 \mathrm{~d}$, salinity was uniformly decreased by mixing natural seawater with distilled water to reach $10 \mathrm{ppt}$, a common salinity in Atlantic croaker nursery areas of the Newport River estuary (Searcy 2005). Fish were then kept under these conditions for the 4 wk experiment. Atlantic croaker were fed recently hatched Artemia ad libitum so that after $24 \mathrm{~h}$ there were still Artemia visible in each container. Prior to the daily feeding, leftover Artemia and waste material were removed, and approximately $33 \%$ of the water was replaced.

To obtain an estimate of size-at-ingress and somatic 'juvenile' growth, digital images of each fish were taken immediately after removal from the alizarin stain solution (assumed length-at-ingress) and at weekly intervals until the end of the experiment. To ensure accurate length measurements, Atlantic croaker were decanted into a narrow glass container that restricted fish from moving horizontally (turning right or left), and positioned in front of a metric ruler. A total of 5 to 10 images of each fish were taken using a macro lens attached to a digital camera. Weekly measures of standard length $(0.1 \mathrm{~mm} \mathrm{SL})$ for individual fish were calculated by taking the average of the 3 best (individually calibrated) digital images using Image-Pro Plus 4.5 image analysis software.

Data analysis: The relationship between juvenile somatic growth in the laboratory and larval history (estimates of larval otolith growth, age-at-ingress, and standard length-at-ingress) was examined using multiple regression analysis. The response variable of individual juvenile somatic growth was calculated by subtracting SL at the end of the experiment from SL at the beginning of the experiment. Daily larval otolith growth was obtained by taking the average of otolith increment widths between 21 and $30 \mathrm{~d}$ post-hatch. Age-at-ingress was measured as the number of otolith increments from the core of the otolith to the alizarin mark and length-atingress was defined as the SL of each fish at the start of the experiment. In the multiple regression analysis, the independent contribution of each of the larval characteristics was estimated using the coefficient of partial determination (squared partial correlation coefficients) with type II sums of squares (PROC REG, SAS Institute). Next, to compare the relationship between juvenile and larval growth in the laboratory study with field results (presented in 'Results'), the Pearson correlation coefficient was calculated between juvenile (41 to $45 \mathrm{~d}$ ) and larval ( 21 to $30 \mathrm{~d}$ ) otolith growth. The $10 \mathrm{~d}$ (31 to $40 \mathrm{~d}$ ) not included in either the larval or juvenile stages represents the ingress period (see 'Results') and is used to conservatively separate the 2 life-history periods.

Field study. The field study examined the relationship between juvenile and larval Atlantic croaker growth over a range of environmental conditions.

Collection method: Collection stations bracketed expected Atlantic croaker nurseries, and included 1 mid-estuary and 4 river stations in both the White Oak and Newport River estuaries, North Carolina (Fig. 1). Each station was sampled during the last $2 \mathrm{~h}$ of day- 
time floodtide, using a towed $1 \mathrm{~m}$ beam trawl $(1 \mathrm{~mm}$ mesh upper and side panels, $3 \mathrm{~mm}$ mesh bottom panel). At each station, 3 replicate tows of 1 min each were completed, covering an area of $\sim 60 \mathrm{~m}^{2}$ each. In total, 7 weekly collections were conducted in the fall (November to December) and spring (February to April) of 2 recruitment seasons (2001-2002 and 2002-2003) in the Newport River estuary, and spring 2002 and fall-spring 2002-2003 in the White Oak River estuary. Bottom temperature and salinity were measured at high tide twice per week at each sampling station, using a handheld YSI-85 instrument (YSI), and in the spring of 2003, hourly measures of these variables were obtained by deploying YSI-6600 multiparameter dataloggers at the head of each estuary (Fig. 1).

Otoliths were removed from a minimum of 30 Atlantic croakers from weekly collections within river nursery areas, and a minimum of 30 Atlantic croakers collected from mid-estuary stations. Otolith records were used to establish range in age at estuarine ingress (mid-estuary collections), to obtain age and growth estimates for individual fish, and to identify weekly hatch-date cohorts (i.e. groups of croaker that were hatched during the same $1 \mathrm{wk}$ period). For each season, otolith growth that occurred prior to the age of the youngest fish collected at the mid-estuary station was assumed to represent larval growth that occurred in the marine environment, and growth that occurred at ages older than the oldest fish collected was assumed to represent juvenile growth within river nursery areas. The otolith age data indicated that Atlantic croaker entered the estuary between 30 and $40 \mathrm{~d}$ posthatch in the fall $(36.7 \pm 3.6 \mathrm{~d}$, average $\pm \mathrm{SD}$, in the White Oak and $36.1 \pm 3.9 \mathrm{~d}$ in the Newport) and 40 to $50 \mathrm{~d}$ post-hatch in the spring $(45.0 \pm 4.1 \mathrm{~d}$ in the White Oak and $45.9 \pm 4.4 \mathrm{~d}$ in the Newport). Therefore, assumed larval and juvenile ages were $<30$ and $>40 \mathrm{~d}$ for the fall, respectively, and $<40$ and $>50 \mathrm{~d}$ for the spring (Fig. 2).

Individual larval and juvenile growth was estimated from analysis of otolith increment widths from fish collected within river nursery areas. Fish condition (Fulton's Condition Factor, weight $\times$ length $^{-3}$, Ricker 1975) was calculated using the SL and dry weight (dried at $60^{\circ} \mathrm{C}$ for $24 \mathrm{~h}$ ) of fish used for otolith analysis. Feeding success on each collection date was calculated using 30 randomly selected fish collected from river nursery areas and recorded as the proportion of fish from each collection date that had empty stomachs.

Data analysis: For analysis of the relationship between juvenile and larval otolith growth from the field collections, only weekly hatch-date cohorts, from which a minimum of 10 fish were aged, were used to calculate Pearson correlation coefficients between juvenile otolith growth (5 d after ingress period) and

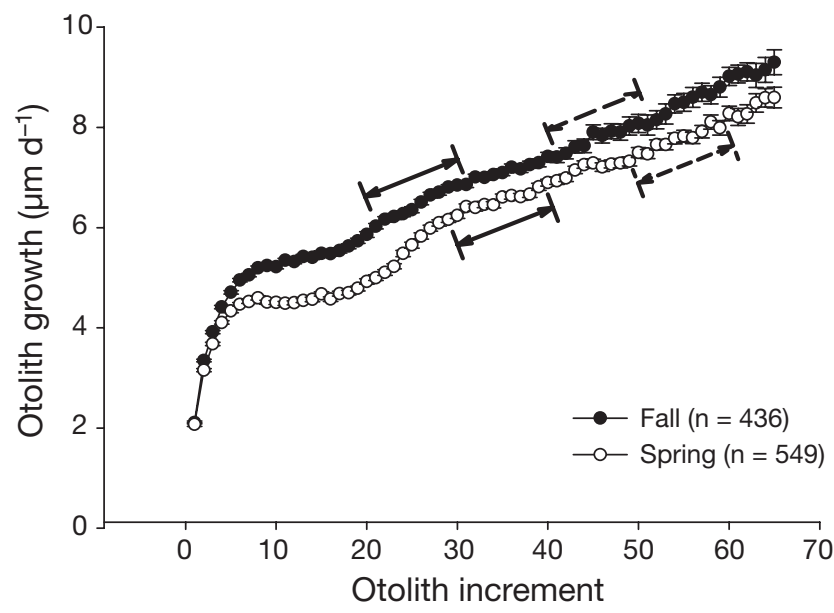

Fig. 2. Micropogonias undulatus. Average otolith growth ( $\pm 1 \mathrm{SE}$ ) for Atlantic croaker collected in fall 2002 and spring 2003 in the Newport River estuary. Regions of otolith growth identified by the double-ended arrows designate the periods of assumed larval (solid lines) and juvenile (dashed lines) growth used in correlation analyses, and the region between the arrows shows the range in ages at which ingress was observed to occur

larval otolith growth (10 d prior to ingress period). These growth intervals were chosen to maximize the number of fish aged that could be used in the analyses and because growth during these intervals was generally linear (Fig. 2).

To address the concern that the relationship between juvenile and larval growth may change from week to week due to differences in length- or age-atingress, separate 1-way ANOVAs tested the null hypothesis that length- and age-at-ingress did not vary significantly within each study season. The total number of weekly mid-estuary collections for which comparisons were possible (minimum of 10 fish aged) in the Newport River estuary was 3 in fall 2001, 5 in spring 2002, 5 in fall 2002 and 5 in spring 2003. For the White Oak River estuary, the total number was 5 in spring 2002, 5 in fall 2002 and 5 in spring 2003.

To examine whether the relationship between juvenile and larval growth changed depending on abiotic and biotic conditions experienced within juvenile nursery areas, multiple regression analysis was used. The univariate correlation between juvenile and larval otolith growth was the dependent variable, while abiotic factors (average weekly temperature, average salinity, and maximum change in salinity) and biotic factors (feeding, condition, catch-per-unit-effort [CPUE], average larval growth, and average juvenile growth) were explanatory variables. Abiotic factors within each estuary were obtained from the sampling station closest to the main body of the estuary (Fig. 1). Temperature and salinity were averaged between the 2 values taken each week and the change in salinity 
between consecutive weeks was taken as a proxy for flooding events. An estimate of feeding ability was defined as the proportion of fish that had empty stomachs and an index of the relative condition of individual fish was calculated by taking the residuals of Fulton's condition factor as a linear function of length. CPUE for each sampling date was calculated by averaging catch per 1 min tow, over 3 tows, from the station in each estuary where most Atlantic croaker were collected.

For multiple regression analysis, all juvenile-larval growth correlation coefficients were used as dependent variables, as even non-significant results likely still capture the direction and general effect size of the relationship. Prior to analysis, data were tested for normality, homogeneous variances, and collinearity (PROC UNIVARIATE and REG, SAS Institute). In addition to standard regression output, the coefficient of partial determination was calculated for each independent variable to estimate the proportion of variability in the juvenile-larval growth correlation coefficients that could be explained by each independent variable, while holding the others constant.

\section{RESULTS}

\section{Laboratory experiment}

There was no evidence for either a positive or negative relationship between juvenile and larval growth. Pearson correlation coefficients between juvenile somatic growth and larval otolith growth $(r=0.05)$, and between juvenile otolith growth and larval otolith growth $(r=0.20)$ were not significantly different than zero. The multiple regression with average somatic juvenile growth as the dependent variable and lengthat-ingress, age-at-ingress, and average larval otolith growth as factors suggested larval history explained a small portion of subsequent juvenile growth $\left(\mathrm{r}^{2}=\right.$ $0.1685, p<0.001)$. The coefficients of partial determination indicated that length-at-ingress was the only statistically significant factor and independently explained $8 \%(t=-2.62, \mathrm{p}<0.01)$ of the variation in somatic juvenile growth; there was a trend for smaller fish-at-ingress to grow faster as juveniles than larger fish-at-ingress (Fig. 3).

\section{Field study}

Significant correlations between juvenile and larval growth occurred over the same time intervals within each estuary. In both estuaries, there was a significant and positive correlation between juvenile and larval

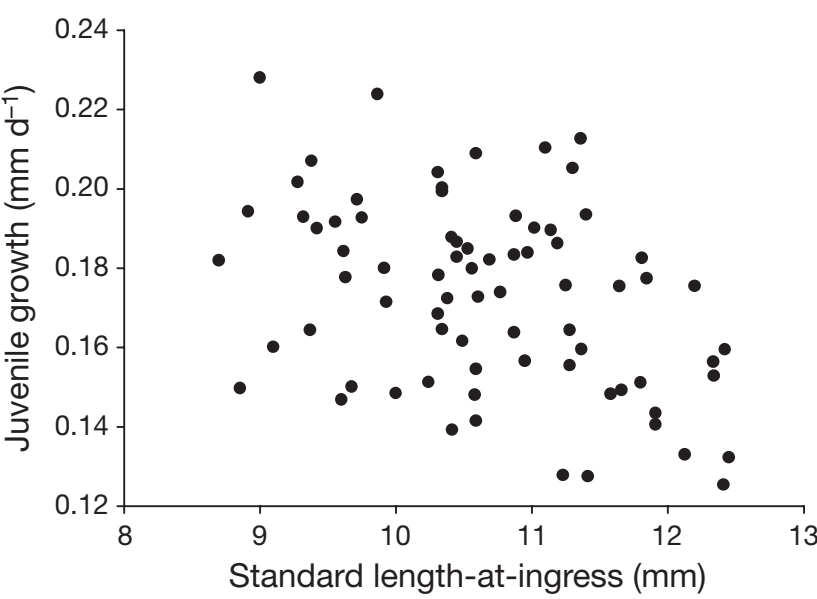

Fig. 3. Micropogonias undulatus. Relationship between average daily juvenile growth measured in the laboratory $(28 \mathrm{~d})$ and length-at-ingress to the Newport River estuary

growth for the same fall 2002 weekly hatch-date cohort, and in spring 2003, 3 significant correlations in the Newport River estuary corresponded with 1 significant and 2 moderately non-significant $(p<0.15)$ correlations in the White Oak River estuary (Fig. 4). Correlation results were likely not the result of cohort-specific life-history traits, as length- and age-atingress did not vary significantly within season for either estuary (1-way ANOVA all ns).

Significant correlations between juvenile and larval growth were related to environmental conditions within each estuary. The multiple regression with the juvenile-larval growth correlation coefficients as the dependent variable and with abiotic factors (average temperature, average salinity, maximum change in salinity) and biotic factors (feeding, condition, CPUE, average larval, and average juvenile growth) as explanatory variables was highly significant $\left(\mathrm{r}^{2}=0.74\right.$, $\mathrm{p}<0.01$ ). The coefficients of partial determination revealed that variation in the juvenile-larval growth correlation coefficient was independently accounted for by the proportion of fish that had empty stomachs $(56 \%, t=4.34, \mathrm{p}<0.001)$, individual condition $(26 \%$, $t=2.3, \mathrm{p}<0.05)$, and change in salinity $(27 \%, t=-2.35$, $\mathrm{p}<0.05$; Fig. 5). Average temperature, average salinity, CPUE, average larval and average juvenile growth were all non-significant $(p>0.05)$ in the multiple regression analysis.

\section{DISCUSSION}

Laboratory results suggest that juvenile growth is weakly related to size at estuarine ingress. Fish that were smaller at ingress had faster subsequent growth in the laboratory, which allowed them to reduce the 

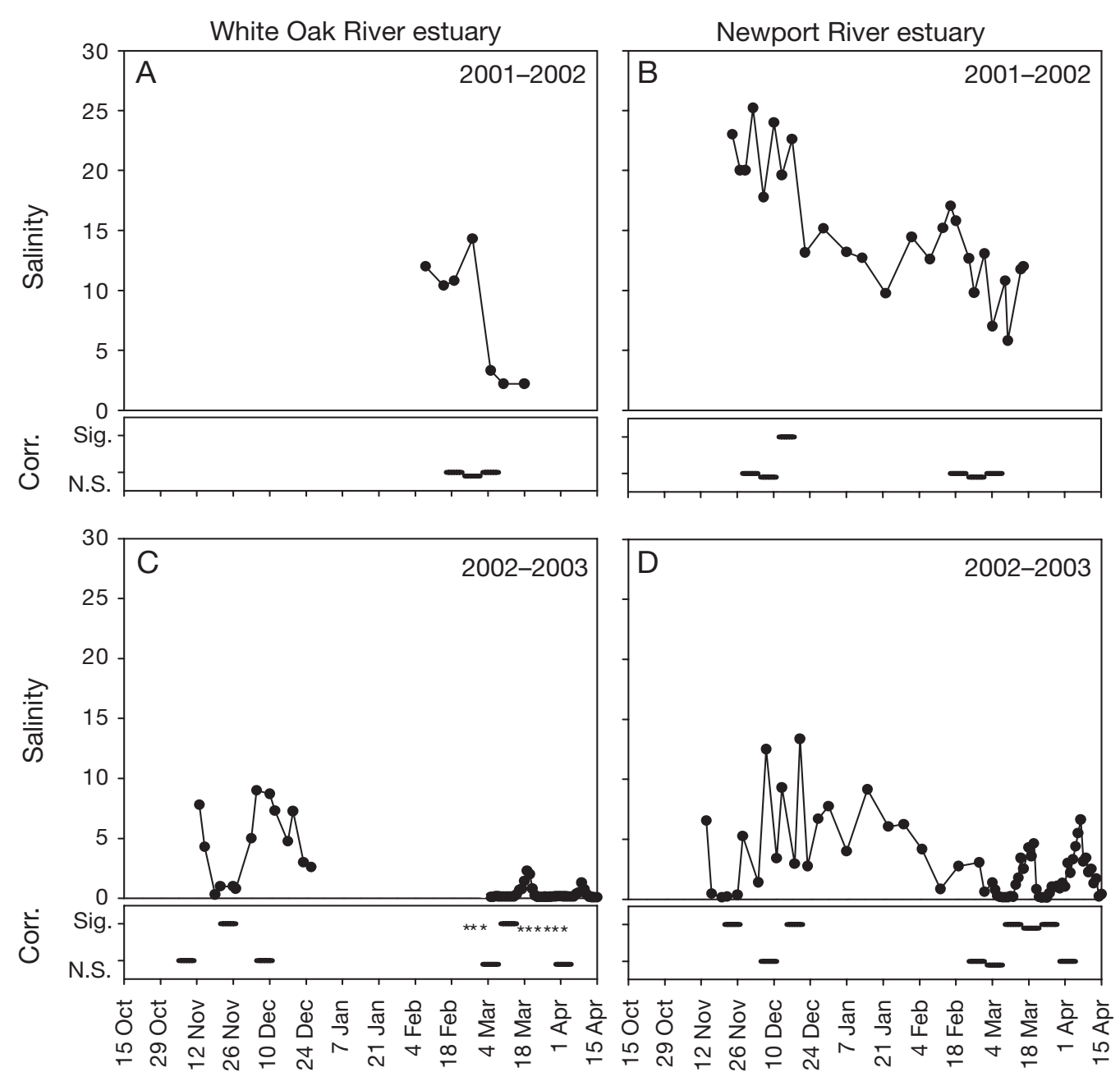

Fig. 4. Micropogonias undulatus. Relationship between salinity and significant correlations (Corr.) between larval and juvenile growth for weekly cohorts of croaker collected in the (A,C) White Oak and (B,D) Newport River estuaries, North Carolina, USA. Both significant (Sig.; $\mathrm{p}<0.05$ ) and non-significant (N.S.) juvenile growth intervals upon which each correlation is based are represented by separate dashes. Juvenile growth intervals that had a moderately non-significant $(p<0.15)$ relationship between larval and juvenile growth are represented by asterisks (C). In the White Oak River estuary no collections were made in fall 2001 (A) and no salinity data are available for winter 2002-2003 (C)

size difference with fish that had entered at larger sizes. Faster growth for relatively smaller individuals in the laboratory study may be attributed to a variety of factors, including smaller individuals being able to feed more effectively on Artemia, as well as smaller individuals remaining on a faster portion of their ontogenetic growth trajectory than relatively larger individuals. One limitation of the laboratory portion of this study, as well as other studies conducted in controlled environments, is the degree to which experimental conditions reflect what actually occurs in natural environments. This is particularly important in studies that have management implications, as misleading information can affect development of effective fishery management actions. In the laboratory study, by using wild-caught fish fed ad libitum, it was possible to determine how natural larval growth variability transferred to patterns of juvenile growth without the confounding effects of variable abiotic conditions, feeding environments, intra- and inter-specific competition, and predation. Such baseline data from a controlled laboratory environment are critical, so that if results in field studies deviate from laboratory results, possible causes can be explored.

In the field component of this study, there was no evidence for a negative relationship between juvenile and larval growth and only limited evidence for a positive relationship. Despite this, the similar temporal pattern of correlations between juvenile and larval growth between the 2 estuaries suggests that processes influencing juvenile growth occurred in both 

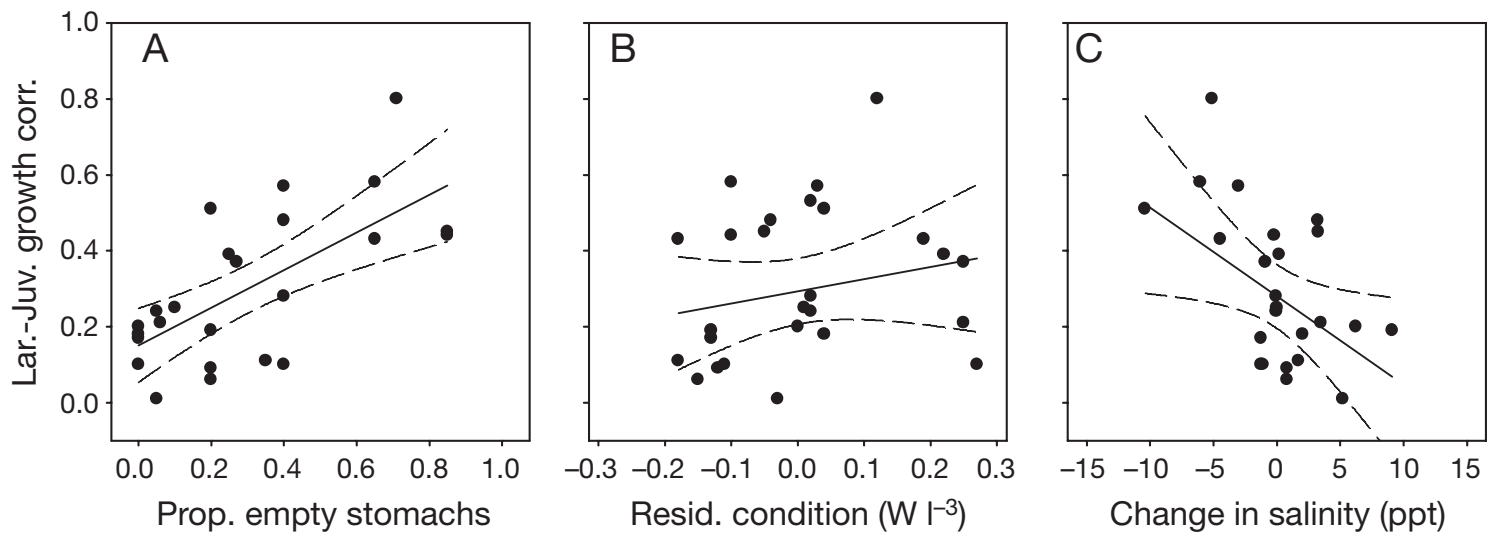

Fig. 5. Micropogonias undulatus. Regression between the correlation between juvenile and larval growth for each weekly hatchdate cohort and (A) proportion of Atlantic croaker with empty stomachs $\left(y=0.57 x+0.1, \mathrm{R}^{2}=0.22\right)$; (B) residual of condition $\left(y=0.11 x-0.03, R^{2}=0.04\right)$; and $(C)$ maximum change in weekly salinity $\left(y=-6.8 x+2.1, R^{2}=0.16\right)$. Dashed lines are $95 \%$ confidence intervals

estuaries simultaneously. Age- and length-at-ingress did not vary significantly within a season; thus, periods when a positive relationship between juvenile and larval growth occurred are likely the product of environmental factors, rather than life-history characteristics. Environmental conditions are known to affect growth patterns of early juvenile of Atlantic croaker (e.g. Peterson et al. 1999, Rakocinski et al. 2000).

Regression results indicate that a positive relationship between juvenile and larval growth may be expressed following a rapid drop in nursery area salinity (as evidenced by a rapid decline in salinity to near 0 ppt, Fig. 3), coinciding with periods when croaker have reduced feeding success. As juvenile Atlantic croaker typically occupy low-salinity habitats (Weinstein 1979, Ross 2003), the positive relationship between juvenile and larval growth is likely related to reduced feeding success caused by high levels of freshwater runoff flushing prey from Atlantic croaker nursery areas rather than salinity-induced physiological constraints.

The relationship between juvenile and larval growth may be related to feeding success through a variety of non-exclusive scenarios. First, rapid larval otolith growth may be associated with higher early-juvenile condition (Hovenkamp \& Witte 1991, McCormick \& Molony 1992, Suthers et al. 1992), and consequently when feeding conditions were poor, individuals with relatively higher condition are able to continue growing faster. This is supported by the partial correlation results, which suggest that cohorts that have higher condition factors are more likely to have a positive relationship between juvenile and larval growth. Second, rapid larval growth may be positively related to development of juvenile feeding structures, such that individuals that are faster growing as larvae are better able to feed as juveniles (McCormick \& Molony 1992,
Pechenik et al. 1998). Although a developmental basis may be responsible for the relationship between juvenile and larval growth, previous studies indicate that recently settled Atlantic croaker are able to consume a variety of pelagic and demersal prey items, which suggests that developmental stage may not be critical to feeding success (e.g. Currin et al. 1984, Soto et al. 1998). Third, previous manipulative field experiments have found that the relationship between juvenile and larval growth may change depending on exposure to different size-ranges of predators (McCormick \& Hoey 2004). Indeed, juvenile Atlantic croaker may have encountered different suites of predators as they moved down-estuary following high levels of freshwater runoff. Regardless of the exact mechanism behind the positive relationship between juvenile and larval growth, evidence that growth during separate life-history stages are not always independent may preclude use of growth as an index of early juvenile habitat quality.

It is important to note that the positive relationship between juvenile and larval growth would not have been observed had this study simply ended with the laboratory component, or if the field study had not spanned a wide-range of environmental conditions. The results suggest that the general growth relationship of no correlation between juvenile and larval growth (as found in our laboratory experiment as well as most cohorts in our field study) may be disrupted by environmental factors. Larval growth histories and environmental conditions within juvenile nurseries should be considered if juvenile traits are used to infer quality of the juvenile environment. Future work on other organisms should recognize the role dynamic environments play in the ability to detect dependence of traits between earlier and later ontogenetic stages. 
Acknowledgements. We are grateful to N. Reyns, H. Sandstrom, M. Lewis and P. McDougall for help during fieldwork, and E. Laban and M. Wuenschel for advice on laboratory components of this project. This manuscript benefited from reviews by J. K. Craig, M. Wuenschel, J. Rice, and J. Miller. This work was supported by the National Sea Grant Office, the National Science Foundation (OCE 0221099), Sigma-Xi, PADI-AWARE, and Budweiser conservation scholarships to S.P.S.

\section{LITERATURE CITED}

Able KW (1999) Measures of juvenile fish habitat quality: examples from a national estuarine research reserve. In: Benaka LR (ed) Fish habitat: essential fish habitat and rehabilitation, Vol 22. American Fisheries Society Symposium, Bethesda, MD, p 43-75

Able KW, Fahay MP (1998) The first year in the life of estuarine fishes on the middle Atlantic bight. Rutgers University Press, New Brunswick, NJ

Ahrenholz DW, Fitzhugh GR, Rice JA, Nixon SW, Pritchard WC (1995) Confidence of otolith ageing through the juvenile stage for Atlantic menhaden, Brevoortia tyrannus. Fish Bull 93:209-216

Basch LV, Pearse JS (1996) Consequences of larval feeding environment for settlement and metamorphosis of a temperate echinoderm. Oceanol Acta 19:273-285

Bergenius MAJ, Meekan MG, Robertson DR, McCormick MI (2002) Larval growth predicts the recruitment success of a coral reef fish. Oecologia 131:521-525

Bertram DF, Chambers RC, Leggett WC (1993) Negative correlations between larval and juvenile growth rates in winter flounder: implications of compensatory growth for variation in size-at-age. Mar Ecol Prog Ser 96:209-215

Chambers RC, Miller TJ (1995) Evaluating fish growth by means of otolith increment analysis: special properties of individual-level longitudinal data. In: Secor DH, Dean JM, Campana SE (eds) Recent developments in fish otolith research. University of South Carolina Press, Columbia, SC, p 155-175

Currin BM, Reed JP, Miller JM (1984) Growth, production, food consumption, and mortality of juvenile spot and croaker: a comparison of tidal and nontidal nursery areas. Estuaries 7:451-459

Hettler WF, Chester AJ (1990) Temporal distribution of ichthyoplankton near Beaufort inlet, North Carolina. Mar Ecol Prog Ser 68:157-168

Hovenkamp F, Witte JIJ (1991) Growth, otolith growth and RNA/DNA ratios of larval plaice Pleuronectes platessa in the North Sea 1987-1989. Mar Ecol Prog Ser 70:105-116

McCormick MI (1994) Variability in age and size at settlement of the tropical goatfish Upeneus tragula (Mullidae) in the northern Great Barrier Reef lagoon. Mar Ecol Prog Ser 103:1-15

McCormick MI, Hoey AS (2004) Larval growth history determined juvenile growth and survival in a tropical marine fish. Oikos 106:225-242

Editorial responsibility: Howard Browman (Associate Editorin-Chief), Storebø, Norway
McCormick MI, Molony BW (1992) Effects of feeding history on the growth characteristics of a reef fish at settlement. Mar Biol 114:165-173

Metcalfe NB, Monaghan P (2001) Compensation for a bad start: grow now, pay later? Trends Ecol Evol 16:254-260

Pechenik JA, Hilbish TJ, Eyster LS, Marshall D (1996) Relationship between larval and juvenile growth rates in two marine gastropods, Crepidula plana and C. fornicata. Mar Biol 125:119-127

Pechenik JA, Wendt DE, Jarrett JN (1998) Metamorphosis is not a new beginning. BioScience 48:901-910

Peterson MS, Comyns BH, Rakocinski CF, Fulling GL (1999) Does salinity affect somatic growth in early juvenile Atlantic croaker, Micropogonias undulatus (L.)? J Exp Mar Biol Ecol 238:199-207

Phillips NE (2002) Effects of nutrition-mediated larval condition on juvenile performance in a marine mussel. Ecology 83:2562-2574

Rakocinski CF, Comyns BH, Peterson MS (2000) Relating environmental fluctuation and the early growth of estuarine fishes: ontogenetic standardization. Trans Am Fish Soc 129:210-221

Ricker WE (1975) Computation and interpretation of biological statistics of fish populations. Bull Fish Res Board Can 191:1-382

Ross SW (2003) The relative value of different estuarine nursery areas in North Carolina for transient juvenile marine fishes. Fish Bull 101:384-404

Searcy SP (2005) Is growth a reliable indicator of essential fish habitat? PhD thesis, North Carolina State University, Raleigh, NC

Searcy SP, Sponaugle S (2000) Variable larval growth in a coral reef fish. Mar Ecol Prog Ser 206:213-226

Searcy SP, Sponaugle S (2001) Selective mortality during the larval-juvenile transition in two coral reef fishes. Ecology 82:2452-2470

Sogard SM (1997) Size-selective mortality in the juvenile stage of teleost fishes: a review. Bull Mar Sci 60: 1129-1157

Soto MA, Holt GJ, Holt SA, Rooker JR (1998) Food habits and dietary overlap of newly settled red drum (Sciaenops ocellatus) and Atlantic croaker (Micropogonias undulatus) from Texas seagrass meadows. Gulf Res Rep 10:41-55

Sponaugle S, Cowen R (1994) Larval durations and recruitment patterns of two Caribbean gobies (Gobiidae): contrasting early life histories in demersal spawners. Mar Biol 120:133-143

Suthers IM, Fraser A, Frank KT (1992) Comparison of lipid, otolith and morphometric condition indices of pelagic juvenile cod Gadus morhua from the Canadian Atlantic. Mar Ecol Prog Ser 84:31-40

Thorrold SR, Hare JA (2002) Otolith applications in reef fish ecology. In: Sale PF (ed) Coral reef fishes: dynamics and diversity in a complex ecosystem. Academic Press, San Diego, CA, p 243-264

Weinstein MP (1979) Shallow marsh habitats as primary nurseries for fishes and shellfish, Cape Fear River, North Carolina. Fish Bull 77:339-357

Submitted: October 10, 2006; Accepted: June 24, 2007

Proofs received from author(s): October 29, 2007 